\title{
MDs call for socially responsible investments
}

Physicians for Global Survival (PGS) is calling on MD Management Ltd., a wholly-owned subsidiary of CMA, to divest its armaments industry investments and develop its own socially responsible investment funds.

In a letter to the chair of CMA's board of directors Dr. Allan Connolly, the past president of PGS, urged MD Management to provide "its physician clients with the option of not investing in the armaments industry." As Connolly wrote in January, "The impact on public health of small arms, antipersonnel mines and conventional warfare technology requires no explanation."

PGS, the Canadian arm of International Physicians for the Prevention of Nuclear War, also wants MD Management financial consultants to be familiar with existing third-party socially responsible funds.

In a written response, Robert Hewett, president and CEO of MD Management, stated that the company "has not observed any demand for a restriction on investments in the armaments industry or any significant demand for MD-branded socially responsible funds.

"To address all the health and environmental concerns of all our clients would be impossible, since each investor may have a personal definition of what they consider ethical," Hewett wrote. "The cost of establishing ethical funds would be significant and would require us to pass along those costs to our clients."

MD clients can purchase ethical funds through the company's consolidated account, Hewett added. That account allows investors to buy third-party funds such as the Real Assets Social Leaders Fund.

In an interview, Hewett said the CMA board has directed MD Management not to invest in tobacco companies, but has issued no such directive relating to armament manufacturers.

A spokesman for PGS says that most physicians likely don't know that they may be investing in armament companies. In terms of professional responsibility and the ethics of the Hippocratic oath, says Dr. Neil Araya, doctors should not be "investing in things that kill people."

"What they're telling us is that it's not a matter of ethics," Araya says. "I guess physicians have to let them [MD Management] know that this is of interest to us." - Laura Eggertson, CMA7

\section{Medical Politics}

\section{Critical time for health care says new CMA President}

Although Dr. Ruth CollinsNakai doesn't officially become CMA's new president until August 17 , she has effectively been on the job since the Chaoulli decision.

"It's a critical time for health care in Canada because the way we react to this challenge may determine the future direction of health care," says CollinsNakai, a pediatric cardiologist and professor of pediatrics at the University of Alberta. "Personally, I don't ever want to see a situation in Canada where a patient cannot get service because they can't afford to pay. That's unacceptable."

On June 9, the Supreme Court of Canada ruled in favour $\because$ of a Quebec patient and Dr. Jacques Chaoulli, who challenged the province's ban on private health insurance for medically necessary services (CMA7 2005;173:139).

Collins-Nakai, the first CMA president with an MBA, says that in the highly emotional private-public debate "you can move forward ... through the common ground, which in this case is putting patients first."

"There are practical things we can look at without getting into pros and cons of a parallel private system," she says.

For example, Canada can set acceptable wait times. As spokesperson for the Wait Time Alliance of Canada, CollinsNakai says the Alliance's final report, expected to be presented at CMA General Council (Aug. 14-17), will be a "tool box for provinces."

Other practical initiatives concern reducing some of the financial burden on Canadians who now pay out-of-pocket for about $30 \%$ of health care costs. "If we're going to increase private costs then we want to make sure [these] costs are minimized." This could entail advo- cating for stiffer regulations for the insurance industry and the generic drug industry.

She also hopes to introduce preventive initiatives to make the system sustainable in the long term. In particular, she'd like to improve the health of children and encourage Canadians to exercise. CollinsNakai literally walks the talk, wearing a pedometer to ensure she takes her 10000 steps daily.

"We're going to have lots of fun this year," says CollinsNakai. Certainly, it will be busy. Although she's

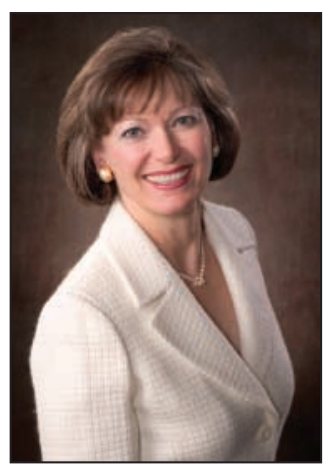

Dr. Collins-Nakai: A critical time for health care. taking a sabbatical from the University of Alberta where she is a professor and clinician, she is beginning a Phase III multicentre clinical trial involving 2000 patients for a new cardiac drug. - Barbara Sibbald, CMAJ 